\title{
New tetraheterafulvalenes, metal 1,2- diheterolenes and some of their products
}

\author{
G.C.Papavassiliou
}

Theoretical and Physical Chemistry Institute, National Hellenic Research Foundation

48, Vassileos Constantinou Ave., Athens 11635

Greece

\begin{abstract}
A number of tetraheterafulvalenes and metal 1,2-diheterolenes prepared were converted to their charge transfer complexes, cation radical salts and cation deficient metal 1,2-diheterolenes by chemical or electrochemical procedures. Some of these compounds were found to be conducting solids.
\end{abstract}

Using the compounds (1)-(24) as starting materials, a number of tetraheterafulvalenes of the types (I) and (II) and metal 1,2-diheterolenes of the types (III) and (IV) have been prepared by methods similar to those reported in<smiles>COC(=O)C1SC(=S)SC1C(=O)OC</smiles><smiles>COC(=O)C1SC2SC1S2</smiles>

(3)<smiles></smiles>

(2)<smiles>C=CC1=C(COC)CC(=[Se])[Se]1</smiles>

(4)<smiles>COC(=O)CSc1sc(=S)sc1SCC(=O)OC</smiles>

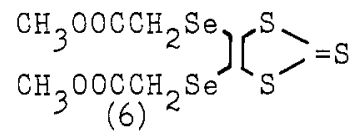<smiles>COC(=O)C1SC2SC(=S)SC2S1</smiles>

(7)<smiles>COC1[Se]c2sc(=[As])sc2[Se]1</smiles>

(8)<smiles></smiles>

(13)<smiles>S=[SH]c1nsc(S)c1Sc1ncsn1</smiles>

(14)<smiles>SC1=C(S)Sc2ccccc2S1</smiles>

(19)<smiles>[Se]=C1SC2COC(OC2)S1</smiles>

(20)<smiles>[R5]CC1SC(=S)SC1[R8]</smiles>

(9)<smiles>[R5]C1[Se]C2[Se]=C1[Se]CC2[R5]</smiles>

(11)<smiles></smiles><smiles></smiles>

(15)

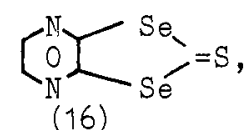

(16)<smiles>Cc1sc(=S)sc1C</smiles>

(21)<smiles>[R5]c1[se]c(=[Se])[se]c1[R15]</smiles>

(12)

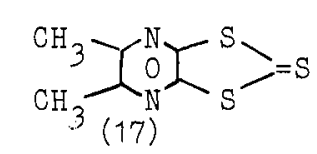

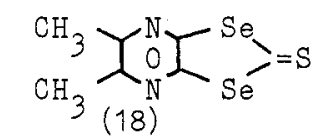<smiles>S=c1sccs1</smiles>

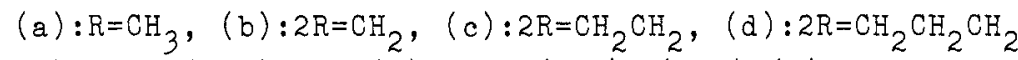
(e) $: 2 \mathrm{R}=\mathrm{CH}\left(\mathrm{CH}_{3}\right) \mathrm{CH}_{2},(\mathrm{f}): 2 \mathrm{R}=\mathrm{CH}\left(\mathrm{CH}_{3}\right) \mathrm{CH}\left(\mathrm{CH}_{3}\right),(\mathrm{g}): 2 \mathrm{R}=\mathrm{CH}=\mathrm{CH}$ 
ref.1 (and refs. cited therein). From these compounds a number of charge transfer complexes, cation radical salts and cation deficient meta1 1,2-diheterolenes have been prepared by chemical or electrochemical procedures (ref.1).Some of them were found to be conducting solids. Recently, a number of new oxygen -containing compounds have been prepared and studied. Pyrazino-ethylenedioxo-<smiles>[X]C([X])C([X])[X]</smiles>

(I)

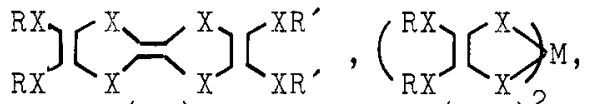

(II)<smiles>[X]C([Y])=C([X])[X]C([Y])(C)C</smiles>

(IV)

-diselenadithiafulvalene (PEDODSDTF), $\left(m p=202^{\circ} \mathrm{C}\right)$ for example, has been prepared (ref.2) by cross-coupling reaction of 4,5-ethylenedioxo-1,3-dithiole-2-one [(20) with 0 instead of Se, to avoid possible rearrangements of $S$ and Se] (see

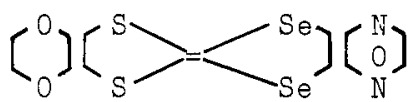

(PEDODSDTF)<smiles>C1=CSC(=C2SC3OCCOC3=[SH]2)S1</smiles>

(EDOTTF)

refs. 2,3) and pyrazino-1,3-diselenole-3-one [(16)with 0 instead of Se](ref.4) via triethyl phosphite. Fig.1 shows the UV-visible spectrum of PEDODSDTF and the spectra of bis (ethylenedioxo) tetrathiafulvalene (BEDO-TTF) and bis (pyrazino) tetraselenafulvalene (BPTSF), for comparison. Also, ethylenedioxo-tetrathiafulvalene (EDOTTF) (mp=92 C) has been prepared from 4,5-ethylenedioxo-1,3-dithiole-2-one and 4,5-bis(methylcarboxy)-1,3-dithiole-2-thione by a two steps sequence (: coupling via triethylphosphite and decarboxylation with LiBr in hexamethylphosphoramide) ( $r e f .2)$. It has been found that PEDODSDTF and EDOTTF are $i$ donors and give with TCNQ, $\mathrm{Bu}_{4} \mathrm{NI}_{3}$ and $\mathrm{Bu}_{4} \mathrm{NIBr}_{2}$, for example, black
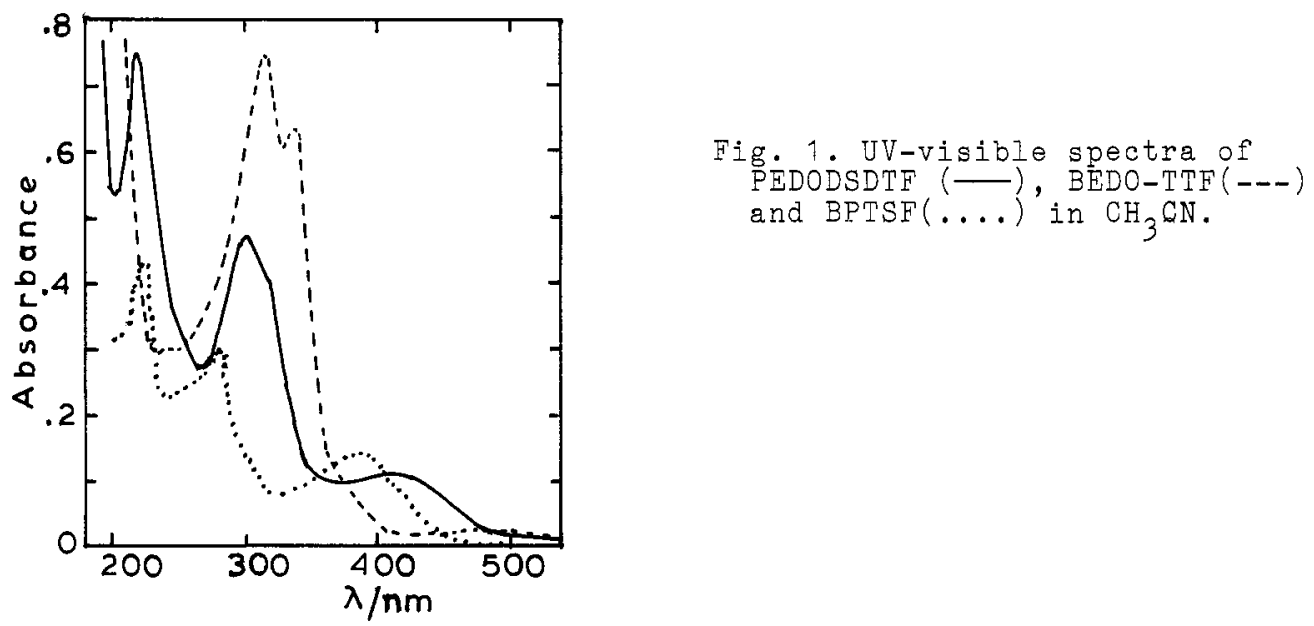

conducting needles or plates. Similar results have been obtained from a number of oxygen,sulfur- or selenium-containing tetraheterafulvalenes. However, details on the preparation and physical properties of these solid products will be published elsewhere $(r e f s, 5,6)$.

\section{REFERENCES}

1. G.C.Papavassiliou "Design and Synthesis of polyheterotetraheterafulvalenes, Metal 1,2-diheterolenes and their low-Dim. cond. and supercond. salts" in "Proc. of NATO-ASI, on Lower-Dim. Systems and Mol. Electronics"Spetses Island, Greece, 12-23 June, 1989, Ed.R.M.Metzger, Plenum, in press.

2. G.C.Papavassiliou, D. Lagouvardos, V.Kakoussis, G.Mousdis, to be published.

3. T.Suzuki, H.Yamochi, G.Srdanov, K.Hinkelmann and F.Wudl, J.Am.Chem.Soc. 111 , 3109 (1989).

4. G.C.Papavassiliou, S.Y.Yiannopoulos, J.S.Zambounis, K. Kobayashi, and K. Umemoto, Chem.Lett., 1279(1987).

5. G.C.Papavassiliou, A.Terzis, B.Hilti, and C.W.Mayer "Cond.and Supercond.Solids Based on MDTTF, EDTTTF" etc". in "Proc. of lst ISSP Int.Symp. Phys.Chem. of Org.Supercond.", Tolyyo, Japan, 27-30-August, 1989, Ed.G.Saito,Springer-Verlag, to be published.

6. G.C.Papavassiliou et al,Mol.Cryst.Liq.Cryst., to be published. 